\title{
References
}

1. Artemova O. I. Rozvytok kreatyvnoho potentsialu maybutnikh praktychnykh psykholohiv v protsesi profesiynoyi pidhotovky / O. I. Artemova // Psykholohiya: realnist i perspektyvy : zb. nauk. pr. Rivnen. derzh. humanit. un-tu. - 2014. - Vyp. 3. - S. 19-22.

2. Vishnyakova N. F. Psikhologicheskiye osnovy razvitiya kreativnosti v professional'noy akmeologii : avtoref. dis. ... d-ra psikhol. nauk : 19.00.03 / N. F. Vishnyakova. - M., 1996. - 24 s.

3. Druzhynina I. A. Rol i mistse treninhovykh tekhnolohiy u pidhotovtsi praktychnoho psykholoha / I. A. Druzhynina // Psykholohichni perspektyvy. - 2011. - T. 3. - S. 204-211.

4. Fedorchuk V. M. Rol veduchoho v orhanizatsiyi psykholohichnoho treninhu : treninh osobystisnoho zrostannya [Elektronnyy resurs] / V. M. Fedorchuk. - Rezhym dostupu : http://pidruchniki.com

Artemova O.I., Druzhynina I.A. CREATIVITY AS A GUARANTEE OF PROFESSIONALISM OF THE LEADING TRAINING GROUPS.

The aim of the article is to study the peculiarities of the development of creativity as a professional and personal quality of the future practical psychologist in the process of conducting training sessions and training of training group instructors.

The training of practical psychologists in various aspects of professional activity involves the use of a wide range of forms and methods of training. One way to overcome the reproductive approach in the training of practical psychologists is to increase the activity of subjects of the educational process and the introduction of active-creative forms and methods of training future specialists. A striking feature of active-creative methods is conducting various types of trainings and effective training of training group instructors, which should be mastered by every psychologist. The effectiveness of the training depends on the personality of the trainer, on his ability to create in the group the atmosphere of empathy, sincerity, self-disclosure, warm relations between the members of the group and the instructor. Creativity is the personal quality that allows the trainer to take care of creating the most favorable conditions for self-knowledge, selfactualization and development of team members, which ensures the effectiveness of the training work.

Problems of the training of future practical psychologists to work with different categories of clients are disclosed through the disclosure of the creative potential of training group instructors. The trainer must have a great deal of patience because during the course of his work he can meet quite different people, encounter with various problems, which require endurance, volitional self-control, flexible and divergent thinking. Training itself is the most effective technology of teaching specific skills and abilities, and creativity - a personality trait, a guarantee of professionalism.

Key words: creativity, personality trait, professionalism, training, training technologies, training group instructor.

\section{МЕТОДОЛОГІЯ КОМПЛЕКСНОГО ПСИХОЛОГІЧНОГО ДОСЛІДЖЕННЯ ПРОБЛЕМИ ФОРМУВАННЯ ПРОФЕСІЙНО-ОСОБИСТІСНОГО СТАНОВЛЕННЯ МАЙБУТНІХ МЕНЕДЖЕРІВ В УМОВАХ ВНЗ}

Стаття присвячена теоретичному аналізу проблеми професійно-особистісного становлення майбутніх менеджерів у прочесі фахової підготовки. Розкривається сутність понять «особистість» та «становлення», необхідних для глибокого вивчення процесу формування досліджуваної проблеми. Автор надає обтрунтування теоретикометодологічних засад вивчення питання психології професійно-особистісного становлення майбутніх менеджерів. Подано приклади емпіричних методів дослідження, які 
слугуватимуть основою в проиесі психодіагностування професійних та особистісних характеристик майбутніх менеджерів, щз у подальшому забезпечуватиме успішність формування професійної компетентності і професійно-управлінської діяльності майбутніх фахівиів у конкурентному середовищі підприємств.

Ключові слова: особистість, становлення, менеджер, психологічна діагностика, фахова підготовка, професійні стандарти, професійно-управлінська діяльність, професійна компетентність.

Статья посвящена теоретическому анализу проблемы профессиональноличностного становления будущих менеджеров в процессе профессиональной подготовки. Раскрывается сущность понятий «личность» и «становление», необходимых для глубокого изучения прочесса формирования исследуемой проблемьл. Автор предоставляет обоснование теоретико-методологических основ изучения вопроса психологии профессиональноличностного становления будущих менеджеров. Подано примеры эмпирических методов исследования, которые могут служить основой в проиессе психодиагностики профессиональных и личностных характеристик будущих менеджеров, в дальнейшем обеспечивая успешность формирования профессиональной компетентности $u$ профессионально-управленческой деятельности будущчих спещиалистов в конкурентной среде предприятий.

Ключевые слова: личность, становление, менеджер, психологическая диагностика, профессиональная подготовка, профессионально-управленческая деятельность, профессиональная компетентность.

Постановка проблеми. Згідно з Національним класифікатором України ДК 003:2010 «Класифікатор професій» від 01.11.2010 р., за основу розроблення якого було прийнято Міжнародну стандартну класифікацію професій (ISCO 88: International Standard Classification of Occupations / ILO, Geneva) та «Професійних стандартів» від 3.05.2017 р., де затверджено вимоги до кваліфікації працівників, їх професійної компетентності, що визначаються роботодавцями і слугують основою для формування професійних кваліфікацій (ст. 33-1 Закону України «Про професійно-технічну освіту» від 10.02.1998 № 103/98-ВР), випливає те, що сучасна економічна індустрія потребує висококваліфікованих менеджерів. Для майбутнього фахівця важливими якостями стають націленість на результат, здатність швидко навчатися, аналітично мислити, а також комунікабельність, ініціативність, відповідальність, вміння працювати в різних групах колективу.

На сучасному етапі постання оптимізації управління організаціями професійне становлення особистості майбутнього менеджера як суб'єкта управлінської праці стає формою його самореалізації. Професійна підготовка, здобута в процесі фахової підготовки психологічно сформованого висококваліфікованого керівника у сфері управління, пов'язана не стільки з неуспішним навчанням, скільки з труднощами професіоналізації майбутнього менеджера. Отже, процес формування професійно-особистісного становлення майбутніх менеджерів під час фахової підготовки та подолання розбіжностей між задоволенням потреб споживчого ринку і особистісним становленням управлінця як професіонала стає пріоритетним завданням вищої школи.

Аналіз останніх досліджень і публікацій. Розглядаючи психологію управління як певну систему знань, учені приділяють спеціальну увагу особі та діяльності керівника. Так, систематизація Є. С. Вендрова і Л. І. Уманського [17] включає три підсистеми психології управління: соціально-психологічні питання управління виробничими групами та колективами (підсистема «людина-колектив»), психологію діяльності керівника, зокрема добору та підготовки кадрів (підсистема «людина-людина»), інженерну психологію управління (підсистема «людина-техніка»). В. Д. Рубахін та О. В. Філіппов [17] пропонують дещо більше зрізів психології управління: функціонально-структурний аналіз управлінської діяльності, інженерно-психологічний аналіз побудови системи «людина-машина», соціальнопсихологічний аналіз виробничих та управлінських колективів, стосунки між керівниками й 
підлеглими, психологія керівника, добір, розташування та спеціальна підготовка управлінських кадрів.

Звертаючись до аналізу сучасного етапу досліджень у актуальній для нас галузі, виділимо, що чисельні запити практики спонукають вчених до активної розробки проблем професіоналізації керівника. На сьогодні в Україні психологія професійного становлення керівника є доволі потужним, динамічним та розгалуженим напрямом наукових розробок, iї сучасний стан сповна розкривається в працях, присвячених висвітленню місця і ролі керівника (менеджера) в управлінському процесі (Л. М. Карамушка, В. М. Шепель, Л. С. Орбан-Лембрик, Л. І. Скібіцька, В. В. Третьяченко, І. М. Семенов, Г. В. Ложкін та ін.). Різні аспекти управлінської діяльності, забезпечення успішного розвитку підприємств та організацій грунтовно проаналізовано в дослідженнях Є. Ф. Іпатова, I. О. Кулініч, Л. Є. Довгань та ін. У численних працях (Є. Є. Вендров, Л. І. Уманський, В. Д. Рубахін, О. В. Філіппов) по-різному приділяють увагу діяльності керівника, розглядаючи психологію управління як певну систему знань.

3 початку XXI ст. проблема психологічних та етичних засад компетентності менеджера в Україні досліджувалася у працях Л. В. Балабанової [1], Л. І. Скібіцької [16], Л. Е. Орбан-Лембрик [10], Є. І. Ходаківського, Ю. В. Богоявленської та Т. П. Грабар [17], В. С. Лозниці [9] та ін. Різні аспекти управлінської діяльності, забезпечення успішного розвитку підприємств та організацій грунтовно проаналізовано в дослідженнях С. Ф. Іпатова [7], І. О. Кулініч [8], Л. Є. Довгань [4] та ін. Проблема психодіагностики висвітлена у дослідженнях М. Акімової [13], К. Гуревич [2], І. Галяна [3] та ін. Науковці наводять відомості про історію виникнення психологічної діагностики, періоди їі становлення, новітні течії та тенденції розвитку. У літературі представлено групи методик, загальні вимоги до них, їх позитивні і негативні характеристики, можливості та обмеження, варіанти інтерпретації. У свою чергу наукові праці стають помічником практичному психологу кваліфіковано i якісно здійснювати діагностичну роботу, вміло використовуючи іï результати у власній професійній діяльності. Психолого-педагогічні питання формування особистості в навчально-виховному процесі представлені у роботах [5] С. Максименка, П. Підкасистого, В. Сластєніна та інших дослідників.

Незважаючи на присутність у сучасній науково-психологічній літературі досліджень, присвячених проблемі формування професійно-особистісного становлення майбутніх спеціалістів різних сфер управління, вона залишається однією з найбільш дискусійних, адже сам феномен досліджуваної проблеми набуває складності у процесі вивчення професійної свідомості та професійної компетентності особистості. Саме проблема психологічного діагностування професійно-особистісного становлення майбутніх управлінців потребує вирішення. Це пов'язано з тим, що запропоновані в наукових джерелах методики дослідження професійних та особистісних характеристик фахівців різних напрямів підготовки не відображають виняткову специфіку роботи менеджерів як спеціалістів управлінського персоналу.

Формулювання цілей статті. Мета статті полягає у розкритті сутності процесу психодіагностики психологічних характеристик професійно-особистісного становлення майбутніх менеджерів у контексті їхньої підготовки у вищих навчальних закладах, що надалі виступатиме базою для одержання надійних результатів. Виходячи із зазначеної мети, завданнями даного дослідження є теоретичний аналіз літературних джерел та обгрунтування теоретико-методологічних засад вивчення питання психології професійно-особистісного становлення майбутніх менеджерів у процесі фахової підготовки.

Виклад основного матеріалу дослідження. Висвітлення сутності процесу діагностики психологічних характеристик професійно-особистісного становлення майбутніх менеджерів у фаховій підготовці потребує розгляду дефініцій «особистість» та «становлення».

Визначення терміну «особистість» міститься у працях Л. Буєвої, О. Ковальова, С. Максименка, Т. Титаренкової. Термін «особистість»- не лише психологічна дефініція. Вона вивчається вона всіма суспільними науками - філософією, соціологією, етикою, 
педагогікою та ін. Розумінню природи особистості сприяють література, музика, образотворче мистецтво. Особистість відіграє значну роль у вирішенні політичних, економічних, наукових, культурних, технічних проблем, загалом у піднесенні рівня людського буття [11]. Особистість є складною системою, що саморозвивається, тобто - сама моделює і реалізує власну генезу. Для того, щоб науково дослідити цей процес, а отже, й дослідити саму особистість, ми маємо створити такі способи і форми вивчення, які б не переривали й не зупиняли його штучно, а - викликали, співіснували б із ним [5].

Отже, особистість - це людина у формації соціально-суспільних психологічних характеристик, які проявляються в загальних зв'язках і визначають морально-етичну поведінку людини. Поняття становлення відноситься до категоріального апарату психології, педагогіки, філософії, соціології та інших галузей знань. В. Слободчиков наголошує, що становлення особистості пов'язане 3 прийняттям індивідом вироблених у суспільстві загально-соціальних функцій і ролей, соціальних норм і правил поведінки, з формуванням умінь будувати відносини 3 іншими. Сформована особистість $є$ суб'єктом вільної, самостійної та відповідальної поведінки в соціальних спільнотах [15]. Е. Ф. Зеєр [6] пояснює, що професійне становлення - це велика частина онтогенезу людини, яка охоплює період 3 початку формування професійних намірів до завершення професійного життя. У цьому гетерохромному процесі можна виділити стадії оптації, професійної освіти та підготовки, профадаптації, професіоналізму і майстерності. Коротко «професійне становлення» можна визначити як формоутворення особистості, яке адекватно діяльності, і індивідуалізацію діяльності особистістю. Особистісне становлення майбутніх менеджерів у професійній діяльності - це одиниця їх онтогенезу в процесі формування професійних цілей до «розквіту» активної професійної-управлінської діяльності.

Отже, професійно-особистісне становлення майбутніх фахівців (менеджерів) у сфері управління - це процес набуття професійних компетентностей, які людина здобуває в ході професійної підготовки, які є відображеними в іiї психіці та усвідомлені нею і які стають іiі особистими компетентностями. У свою чергу професійна компетентність є невід'ємною частиною професійних вмінь та навичок майбутнього спеціаліста. Особистість професійно компетентного майбутнього менеджера відображена в його внутрішній цілісності, де професійне й особистісне тісно взаємопов'язані системою цінностей. Будь-які професійні знання, перш ніж втіляться в діяльності, наповнюються ціннісним змістом, стають внутрішнім переконанням фахівця, частиною його понятійних категорій, установок, поведінкових шаблонів. Професійно значимі індивідуальні якості виступають як належність, в якій зовнішні характеристики й вимоги утворюють індивідуальну значимість майбутнього спеціаліста. Як бачимо, формування професійно компетентного працівника вимагає розвитку всіх компонентів особистісного потенціалу майбутнього фахівця - пізнавального, ціннісного, творчого, комунікативного, соціального, що обумовлює сформованість основного мотиву розвитку потенціалу особистості - потребу в самодіагностиці, саморозвитку та самореалізації [12]. На підставі аналізу наукової літератури з проблематики формування професійно-особистісного становлення майбутніх менеджерів нами було сформовано наступні завдання для подальшого розгляду методології експериментального дослідження: аналіз системи уявлень майбутніх менеджерів про особливості власної управлінської діяльності та іï стильових характеристик (особистісні характеристики); здійснення аналізу сутності професійного становлення майбутніх менеджерів та місце в цьому процесі професійно-управлінського самовизначення.

Експериментальна база дослідження повинна грунтуватися на вивченні та аналізі двох підгруп психологічних характеристик, а саме особистісних та професійних, що у подальшому забезпечуватиме успішність управлінської діяльності майбутніх менеджерів у конкурентних умовах функціонування підприємства (організації). Слід зазначити, що до особистісних характеристик доцільно віднести: творчий потенціал; потребу в досягненнях; необхідність у подальшому розвитку (вдосконаленні); уміння йти на розумний/зважений ризик; потребу в незалежності; цілеспрямованість та рішучість; фізичне та психічне здоров'я. Усі ці характеристики, на особистісному рівні, сприяють розвитку почуття 
співучасті для досягнення корпоративним колективом високих результатів, виховання командного духу, створення професійної команди, націленої на досягнення поставленої мети в представників управлінського персоналу. До складу групи професійних характеристик відносяться: орієнтація на працю; стійкість до стресу; націленість на заробіток; лідерський потенціал; комунікабельність; орієнтація на роботу в команді. Тому для вирішення першого завдання запропонованого експериментального дослідження нами було виокремлено опитувальник «Психогеометрія для менеджерів» (Г. В. Щокін) [18]. Психогеометрія унікальна практична система аналізу особистості. Вона дозволяє: миттєво визначити форму (чи тип) особистості людини; дати характеристику іiі особистих якостей та особливостей поведінки; скласти сценарій поведінки особистості у типових ситуаціях.

У методиці пропонується вибрати з шести представлених фігур ту, щодо якої можна сказати: «Це я!» I, відповідно до обраної фігури, отримати психологічну характеристику основних форм особистості Психогеометрія розроблена у США. Ї̈̈ автор Сьюзен Деллінгер спеціаліст із соціально-психологічної підготовки управлінських кадрів. За останні роки цю систему вивчали більше ніж 100 тис. слухачів шкіл менеджменту. Існують прихильні відгуки 500 «кадровиків» американських компаній, які вважають, що психометрія могла б використовуватись замість традиційного тестування нових службовців. Точність діагностики за допомогою психогеометричного методу досягає $85 \%$ [18]. Адаптацію психогеометричного тесту до вітчизняних умов провели психологи А. А. Алексєєв та Л. А. Громова.

Після здійснення аналізу системи майбутніх менеджерів щодо особливостей власної управлінської діяльності (особистісні характеристики) пропонується перейти до розв'язання другої поставленої перед нами задачі. Для проведення аналізу розвитку професійних характеристик у представників майбутнього управлінського персоналу нами було виділено методики: тест «Методика оцінки стилю управління» (Я.В.Подоляк); опитувальник «Самооцінка стійкості до стресу» (В. С. Лозниця) [9]. Під час виконання тесту «Методика оцінки стилю управління» пропонується об'єктивно відповісти на запитання, які стосуються характеру, ставлення, звичок, схильностей досліджуваного. Для того, щоб точно оцінити майбутній стиль управління за допомогою даного тесту, необхідна не тільки самооцінка, а й аналіз сформованості практичної сторони майбутнього менеджера. Підрахувавши номери відповідних тверджень і скориставшись ключем-таблицею, можна визначити ступінь виявленості авторитарно-одноосібного, пасивно-потуральницького чи одноосібнодемократичного стилю управління. Тест «Методика оцінки стилю управління» призначений для самостійного визначення менеджером ступеня розвитку своїх професійних якостей в ситуаціях управлінської діяльності.

Наступним, завершальним кроком у діагностичному процесі виступатиме вивчення рівня схильності майбутніх менеджерів до стресових ситуацій. Для цього пропонується опитувальник «Самооцінка стійкості до стресу» (В. С. Лозниця), де, підрахувавши сумарну кількість балів, яку отримають респонденти, можна визначити рівень їхньої стійкості до стресу. Адже стрес - це стан психічної напруги, яка виникає під дією різних екстремальних подразників - стресорів, що призводить до росту непередбачуваного функціонального стану - стресу. За даною методикою, чим менше число (сумарне) балів отримають респонденти, тим вища буде стійкість до стресу, і навпаки [9].

Отже, за допомогою запропонованих психодіагностичних тестів та методик можна виявити професійно вагомі характеристики та якості, притаманні окремій особистості, важливі для майбутньої професійної діяльності менеджера.

Висновки 3 даного дослідження і перспективи подалыших розвідок. Отже, надання психодіагностичної оцінки проблемі формування професійно-особистісного становлення майбутніх менеджерів в умовах ВНЗ є доволі актуальною тематикою в контексті проблем вищої школи, адже професійна компетентність $\epsilon$ особистісною характеристикою та безпосередньо пов'язана з вирішенням професійно-управлінських і життєвих питань.

Представлені методики психодіагностування показників професійно-особистісного становлення майбутніх менеджерів відображають проведену нами роботу. Перспективи 
подальших розвідок ми бачимо безпосередньо у проведенні експериментального дослідження та висвітленні отриманих результатів динаміки формування означеного професійно-особистісного становлення майбутніх фахівців. Якщо майбутні отримані дані будуть актуалізувати необхідність здійснення психологічного супроводу, то подальше дослідження проблеми складатиметься із запровадження комплексної корекційної програми щодо процесу формування «здорових» професійно-особистісних характеристик майбутніх менеджерів.

\section{Список використаних джерел}

1. Балабанова Л. В. Організація праці менеджера : підручник / Л. В. Балабанова, О. В. Сардак. - Донецьк : ДонНУЕТ, 2008. - 480 с.

2. Галян I. М. Психодіагностика : навч. посіб. / І. М. Галян. - 2-ге вид., стереотип. Київ : Академвидав, 2011. - 464 с.

3. Гуревич К. М. Дифференциальная психология и психодиагностика. Избранные труды : пособие / К. М. Гуревич. - СПб. : Питер, 2008. - 336 с.

4. Довгань Л. Є. Праця керівника, або практичний менеджмент / Л. Є. Довгань. Київ : ЕксОб, 2002. - 384 с.

5. Загальна психологія : Хрестоматія : Навч. посіб. / О. В. Скрипченко, Л. В. Долинська, 3. В. Огороднійчук [та ін.] - К. : Каравела, 2008. - 640 с.

6. Зеер Э. Ф. Психология профессий : учеб. пособ. для студентов вузов / Э. Ф. Зеер. - М. : Акад. Проект ; Екатеринбург : Делов. кн., 2003. - 336 с.

7. Іпатов Е.Ф. Психологія управління в бізнесі : навч. посіб. / Е. Ф. Іпатов, К. М. Левківський, В. В. Павловський. - [2-е вид., доп., перероб.]. - Харків-Київ : НМЦВО, 2003. - $320 \mathrm{c}$.

8. Кулініч І. О. Психологія управління : навч. посіб. / І. О. Кулініч. - Київ : Знання, 2008. - 292 c.

9. Лозниця В. С. Психологія менеджменту : навч. посіб. / В. С. Лозниця. - Київ : ТОВ «УВПК «ЕксОб», 2001. - 512 с.

10. Орбан-Лембрик Л. Е. Психологія управління : посібник / Л. Е. Орбан-Лембрик. Київ : Академвидав, 2003. - 568 с.

11. П'ятакова Г. П. Сучасні педагогічні технології та методика їх застосування у вищій школі : навч.-метод. посіб. / Г. П. П'ятакова, Н. М. Заячківська. - Львів : Видав. центр ЛНУ імені Івана Франка, 2003. - 55 с.

12. Павелків Р. В. Вікова психологія : підручник / Р. В. Павелків. - Київ : Кондор, 2011. - 469 c.

13. Психодиагностика. Теория и практика : учебник для бакалавров / М. К. Акимова [и др.] ; под ред. М. К. Акимовой. - 4-е изд., перераб. и доп. - М. : Издательство Юрайт, 2014. - $631 \mathrm{c}$.

14. Психологія : Підручник / Ю. Л. Трофімов, В. В. Рибалка, П. А. Гончарук [та ін.]; за ред. Ю. Л. Трофімова. - К. : Либідь, 2008. - 560 с.

15. Скібіцька Л. І. Організація праці менеджера : навч. посіб. / Л. І. Скібіцька. Київ : Центр учб. літ., 2010. - 360 с.

16. Слободчиков В. И. Основы психологической антропологии. Психология человека: введение в психологию субъективности : учеб. пособ. для вузов / В. И. Слободчиков, Е. И. Исаев. - М. : Школа-Пресс, 1995. - 384 с.

17. Ходаківський С. I. Психологія управління : підручник / Є. І. Ходаківський, Ю. В. Богоявленська, Т. П. Грабар. - [3-є вид., перероб, доп.]. - Київ : Центр учб. літ., 2011. $664 \mathrm{c}$.

18. Щокін Г. В. Практична психологія менеджменту: Як робити кар'єру. Як будувати організацію : наук.-практ. посіб. / Г. В. Щокін. - Київ : Україна, 1994. - 399 с.

\section{References}


1. Balabanova L. V. Organizacija praci menedzhera : pidruchnik / L. V. Balabanova, O. V. Sardak. - Donec'k : DonNUET, 2008. - 480 s.

2. Gurevich K. M. Differencial'naja psihologija i psihodiagnostika. Izbrannye trudy: posibnik / K. M. Gurevich. - SPb. : Piter, 2008. - 336 s.

3. Galjan I. M. Psihodiagnostika : navch. posib. / I. M. Galjan. - 2-ge vid., stereotip. Kyiv : Akademvidav, 2011. - 464 s.

4. Dovgan' L. Je. Pracja kerivnyka, abo praktychnyj menedzhment / L. Je. Dovgan'. Kyiv : EksOb, 2002. - 384 s.

5. Zagal'na psihologija : hrestomatija : navch. posib. / O. V. Skripchenko, L. V. Dolins'ka, Z. V. Ogorodnijchuk ta in. - Kyiv : Karavela, 2008. - 640 s.

6. Zeer Je. F. Psihologija professij : ucheb. posob. dlja studentov vuzov / Je. F. Zeer. - M. : Akad. Proekt ; Ekaterinburg : Delov. kn., 2003. - 336 s.

7. Ipatov E. F. Psihologija upravlinnja $\mathrm{v}$ biznesi : navch. posib. / E. F. Ipatov, K. M. Levkivs'kij, V. V. Pavlovs'kij. - [2-e vid., dop., pererob.]. - Harkiv-Kyiv : NMCVO, 2003. $320 \mathrm{~s}$.

8. Kulinich I. O. Psihologija upravlinnja : navch. posib. / I. O. Kulinich. - Kyiv : Znannja, 2008. $-292 \mathrm{~s}$.

9. Loznycja V. S. Psyhologija menedzhmentu : navch. posib. / V. S. Loznycja. - Kyiv : TOV «UVPK «EksOb», 2001. - 512 s.

10. Orban-Lembrik L. E. Psihologija upravlinnja : posibnik / L. E. Orban-Lembrik. - Kyiv : Akademvidav, 2003. $-568 \mathrm{~s}$. 2011. $-469 \mathrm{~s}$.

11. Pavelkiv R. V. Vikova psihologija : pidruchnik / R. V. Pavelkiv. - Kyiv : Kondor,

12. P'jatakova G. P. Suchasni pedagogichni tehnologiï ta metodika ïh zastosuvannja u vishhij shkoli: navch.-metod. posib. / G. P. P'jatakova, N. M. Zajachkivs'ka. - L'viv: Vidav. centr LNU imeni Ivana Franka, 2003. - 55 s.

13. Psihodiagnostika. Teorija i praktika : ucheb. dlja bakalavrov / pod red. M. K. Akimovoj. - 4-e izd., pererab. i dop. - M. : Izdatel'stvo Jurajt, 2014. - 631 s.

14. Psihologija : pidruchnik / Ju. L. Trofimov, V. V. Ribalka, P. A. Goncharuk ta in.; za red. Ju. L. Trofimova. - Kyiv : Libid', 2008. - 560 s.

15. Slobodchikov V. I. Osnovy psihologicheskoj antropologii. Psihologija cheloveka : vvedenie v psihologiju sub\#ektivnosti : ucheb. posob. dlja vuzov / V. I. Slobodchikov, E. I. Isaev. M. : Shkola-Press, 1995. - 384 s.

16. Skibic'ka L. I. Organizacija praci menedzhera : navch. posib. / L. I. Skibic'ka. - Kyiv : Centr uchb. lit., 2010. - $360 \mathrm{~s}$.

17. Hodakivs'kyj Je. I. Psyhologija upravlinnja : pidruchnyk / Je. I. Hodakivs'kyj, Ju. V. Bogojavlens'ka, T. P. Grabar. - [3-je vyd., pererob., dop.]. - Kyiv : Centr uchb. lit., 2011. $664 \mathrm{~s}$.

18. Shhokin G. V. Praktychna psyhologija menedzhmentu: Jak robyty kar'jeru. Jak buduvaty organizaciju : nauk.-prakt. posib. / G. V. Shhokin. - Kyiv : Ukrai'na, 1994. - 399 s.

\section{Bereziuk T. P. METHODOLOGY OF COMPLEX PSYCHOLOGICAL STUDY OF THE PROBLEM OF FORMATION OF PROFESSIONAL AND PERSONAL DEVELOPMENT OF FUTURE MANAGERS IN CONDITIONS OF UNIVERSITY.}

The author focuses on the need to apply the legal basis for creation of professional standards with requirements for the qualification of employees, their professional competence, which are determined by employers and serve as a basis for the formation of professional qualifications, which is a topical issue of the process of education of future managers in Ukraine. Theoretical analysis of the problem of professional and personal formation of future managers in the process of professional training is carried out. The essence of the concepts of "personality" and "formation", which are necessary for a deep study of the process of formation of the problem, is ascertained. It is noted that category of personality in psychological science is one of the basic concepts and is the most important theoretical and methodological problem of the present. The 
author substantiates theoretical and methodological principles of the study of psychology of professional and personal formation of future managers. It is emphasized that professional competence is the main component of professional skills of future managers. Personality of professionally competent future specialist is reflected in his internal continuity, where professional and personal are closely interconnected by a system of values. Examples of methods of empirical research which will serve as a basis for the psychodiagnosis of professional and personal characteristics of future managers, that will ensure the success of the formation of professional competence and professional and management activities of future specialists in the competitive environment of enterprises are presented.

Key words: personality, formation, manager, psychological diagnostics, professional training, professional standards, professional and management activities, professional competence

УДК 159.923.2:316.776.3

\section{Д. О. БІГУНОВ}

\section{МОВЛЕННСВА ПОВЕДІНКА ОСОБИСТОСТІ: КОМУНІКАТИВНІ СТРАТЕГІЇ ТА ТАКТИКИ}

В статті здійснено спробу описати та проаналізувати основні комунікативні стратегї та тактики в мовленнєвій поведінці особистості як необхідні компоненти усвідомленого досягнення мети в прочесі спілкування. Крім того, було розглянуто передумови мовленнєвої стратегії та поняття комунікативного наміру.

Ключові слова: мовленнєва поведінка, мовленнєвий акт, комунікативні стратегії, комунікативні тактики, комунікант, цүілепокладання.

B статье осуществлена попытка описать $u$ проанализировать основные коммуникативные стратегии и тактики речевого поведения личности как обязательные компоненты осознанного достижения ичели в процессе общения. Кроме того, было рассмотрено предпосылки речевой стратегии и понятия коммуникативного намерения.

Ключевые слова: речевое поведение, речевой акт, коммуникативные стратегии, коммуникативные тактики, коммуникант, целеполагание.

Постановка проблеми. Дослідження мовленнєвої поведінки комунікантів є одним 3 актуальних напрямків досліджень у вітчизняній і зарубіжній науці. Незважаючи на значну кількість наукових праць провідних вчених, таких як Р. Блакар, Т.А. ван Дейк, С. ЕрвінТріпп, О.С. Ісерс, Х.Я. Ийм, Г.К. Михальська та ін. присвячену проблемам мовленнєвого спілкування, залишається досить багато питань, які потребують спеціального вивчення. Саме тому метою статті є розгляд мовленнєвих тактик і комунікативних стратегій мовленнєвої поведінки особистості.

Аналіз останніх досліджень і публікацій. Як зазначають дослідники, спілкування між людьми є багатоплановим явищем і різні галузі наук акцентують свою увагу на центральних для себе факторах. Прагматика зосереджується на ставленні людини до мовних знаків, на підборі доречних одиниць в ситуації спілкування, на адресаті. Предметом психолінгвістики є мовна особистість ,яка розглядається в індивідуально-психологічному аспекті. Когнітивна лінгвістика досліджує механізми розуміння, на які спирається людина в процесі формування та розуміння висловлювання. В межах когнітивної науки досліджуються процеси засвоєння, накопичення та використання інформації людиною. Соціолінгвістика досліджує кореляцію мови та соціальних структур, соціальну приналежність адресанта та адресата.

В контексті успішної комунікації необхідно відмітити умови успішності мовленнєвих актів, оскільки далеко не завжди співбесідник реагує на репліки очікуваним чином. Як зазначає Дж. Серль, для опису умов успішності обов'язковим $є$ врахування 